\section{A COMPARATIVE STUDY OF MONITORING METHODS IN SUSTAINABLE PAVEMENT SYSTEM DEVELOPMENT}

Gatot Rusbintardjoa, Chin Meei Jiunb, Ahmad Nazrul Hakimi Ibrahimb $^{b}$, Peyman Babashamsib, Nur Izzi Md. Yusoffb*, Mohd Rosli Haininc

aDept. of Civil Engineering, Faculty of Engineering, Sultan Agung Islamic University, Jalan Raya Kaligawe km. 4 Semarang, 50112 Indonesia

bSmart and Sustainable Township Research Centre, Universiti Kebangsaan Malaysia, 43600 Bangi, Selangor, Malaysia cSchool of Civil Engineering, Faculty of Engineering, Universiti Teknologi Malaysia, 81310 UTM Johor Bahru, Johor, Malaysia
Article history

Received

9 February 2019

Received in revised form

30 May 2019

Accepted

17 June 2019

Published online

26 August 2019

*Corresponding author izzi@ukm.edu.my
Graphical abstract

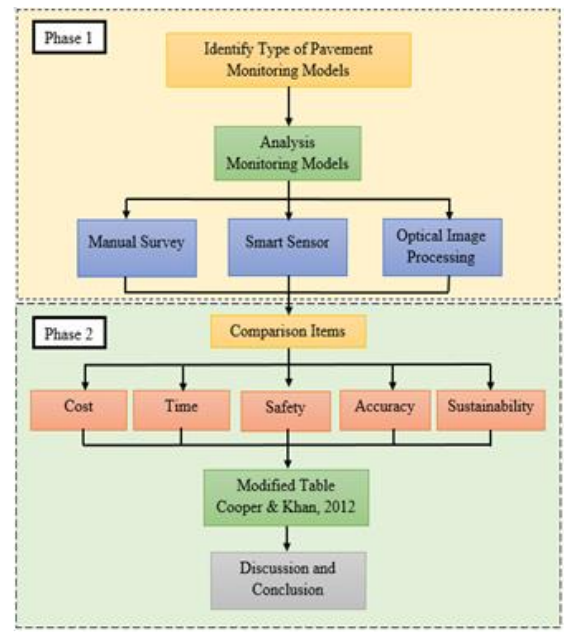

\begin{abstract}
Pavement management system (PMS) has been receiving increasing attention from both the government and private sectors in the attempt to ensure and keep the roads in good condition. The appropriate level of road maintenance activity is often contingent upon the type of pavement distress. Valid and reliable pavement data would lead to develop a PMS which is more suitable for agencies. Previous studies which attempted to identify modes of monitoring pavements were limited by constraints such as cost, time, and safety. This study was conducted to review some of the pavement monitoring modes introduced in previous studies. After completing a literature review, three mostly used modes, namely manual survey, smart sensor, and optical image processing, are selected for a comparative study to determine which mode is the most effective method in terms of cost, time, safety, accuracy, and sustainability. A data quality guideline was modified to produce a rating system for ranking the modes. In conclusion, the findings of this study could provide a guideline for the government and private sectors in determining the most effective pavement monitoring mode to be used in the sustainable PMS strategy.
\end{abstract}

Keywords: Sustainable development, pavement management system, manual survey, smart sensor, optical image processing

\begin{abstract}
Abstrak
Sistem pengurusan turapan semakin meraih perhatian daripada sektor kerajaan dan swasta dalam usaha untuk memastikan dan mengekalkan keadaan jalan raya yang baik. Kesesuaian aktiviti penyelenggaraan jalan adalah bergantung kepada jenis dan tahap kerosakan jalan. Data turapan yang tepat dan boleh dipercayai akan membawa kepada pembangunan sistem pengurusan turapan yang lebih sesuai kepada pelbagai agensi. Kajian lepas telah dijalankan untuk menentukan mod pemantauan turapan dan kekangannya seperti kos, masa dan keselamatan. Kajian ini telah dijalankan untuk mengkaji beberapa mod pemantauan turapan yang telah diperkenalkan dalam kajian-kajian terdahulu. Selepas menjalankan kajian literatur, tiga mod yang sering digunakan, seperti kajian secara manual, pengesan pintar dan pemprosesan imej optik, telah dipilih untuk kajian perbandingan bagi menentukan mod yang paling efektif dari segi
\end{abstract}


kos, masa, keselamatan, ketepatan, dan mampan. Garis panduan kualiti data telah diubahsuai untuk menghasilkan sistem penilaian mod-mod tersebut. Sebagai kesimpulan, dapatan kajian ini dapat menyediakan garis panduan kepada pihak kerajaan dan swasta dalam penentuan mod pemantauan yang paling berkesan untuk digunakan di dalam strategi sistem pengurusan turapan mampan.

Kata kunci: Pembangunan mampan, sistem pengurusan turapan, kajian secara manual, pengesan pintar, pemprosesan imej optik

(C) 2019 Penerbit UTM Press. All rights reserved

\subsection{INTRODUCTION}

Pavement management system (PMS) is established by highway agencies to ensure that roads are in a good condition and serving its purpose. The American Public Works Association [1] defines pavement management as a systematic method for routinely collecting, storing, and retrieving the information required for decision-making in order to ensure that limited maintenance (and construction) dollars are prudently spent. Pavement condition survey is an important element in the pavement management process. A survey of pavement condition will provide the valuable information needed for pavement performance analysis; it is also crucial in facilitating the forecast of pavement performance, anticipating maintenance and rehabilitation requirements, establishing maintenance priorities, and allocating funds [2]. The network-level pavement asset management system (PAMS) proposed by Zhang et al. [3], has become an important tool in helping state highway agencies determine maintenance and rehabilitation schedules and allocating limited resources. Pavements are one of the most important infrastructures which ensure a safe and comfortable journey. However, pavement is a type of consumable material and must be replaced at an appropriate interval since they deteriorate and are damaged by applied load and the effects of surrounding factors, such as heavy traffic, unpredictable climate, etc [4]. Pavement maintenance is essential to ensure a safe travel as well as prevent traffic congestion, air pollution, and accidents [5]. Consequently, PMS is becoming increasingly important since it provides information on pavement condition, which in turn helps authorities schedule, pavement maintenance activities $[3,6,7]$. PMS has brought many benefits to the urban transportation system in the recent years [8]. In order to ensure a good road system, it is essential to continuously maintain and rehabilitate the existing road network [9]. PMS should be able to facilitate the decision making process regarding which segments of a pavement network should be preserved, maintained and rehabilitated despite the budget constraints [10]. Before making a decision on road maintenance, it is important to know the actual condition of pavement in a particular area. Different types of pavement distresses [4, 11] would probably require different treatment. Therefore, data on pavement distress is required before making a decision on the proper rehabilitation treatment to be carried out [12-14].

Several pavement monitoring methods can be employed to gather pavement distress data. Conventional methods, such as walking and riding (also known as windshield) surveys are used to monitor the conditions of pavement surface manually. In addition, pavement distress data also collected via automated surveys. Previous research on PMS were conducted to make a comprehensive assessment of the method used in pavement monitoring as summarized in Table 1. To date, the pavement management authorities worldwide, including Malaysia facing the problem to choose the most effective pavement monitoring method. A comparative study is beneficial to assist the authorities choose the most effective pavement monitoring method by using valid and reliable data to implement a PMS strategy despite the constraining factors. Thus, the aim of this study is to compare the frequently used monitoring methods, including manual survey, smart sensor study, and optical image processing in term of cost, time, safety, accuracy of data, and sustainability. 
Table 1 Recent developments in PMS monitoring modes

\begin{tabular}{|c|c|c|c|c|c|}
\hline Mode & Specific Technology & Years & Authors & Advantages & Measurement \\
\hline \multirow{3}{*}{$\begin{array}{l}\text { Manual } \\
\text { Survey }\end{array}$} & \multirow{3}{*}{$\begin{array}{l}\text { Walking Survey and } \\
\text { Riding Survey }\end{array}$} & 2004 & Timm et al. [6] & \multirow{3}{*}{$\begin{array}{c}\text { Simple to Conduct, Less } \\
\text { Expensive, Detailed } \\
\text { Information Collected, } \\
\text { Greater Amount of } \\
\text { Coverage, Easy to Cover } \\
\text { Entire Width of Road Section }\end{array}$} & \multirow{3}{*}{$\begin{array}{l}\text { Pavement Surface } \\
\text { Distress: } \\
\text { Cracks, Deformation, } \\
\text { Surface and Edge } \\
\text { Defects, Patch and } \\
\text { Pothole }\end{array}$} \\
\hline & & 2011 & $\begin{array}{c}\text { Wolters et al. } \\
{[15]}\end{array}$ & & \\
\hline & & 2013 & $\begin{array}{l}\text { Attoh-Okine \& } \\
\text { Adarkwa [16] }\end{array}$ & & \\
\hline \multirow{8}{*}{ Sensors } & $\begin{array}{l}\text { Fiber Optic Traffic } \\
\text { Sensor (FOTS) }\end{array}$ & $\begin{array}{l}2000 \\
2003\end{array}$ & $\begin{array}{l}\text { Cosentino \& } \\
\text { Grossman [17] }\end{array}$ & $\begin{array}{l}\text { Micro bend Fiber-Optic } \\
\text { Sensing Technology }\end{array}$ & $\begin{array}{l}\text { Weigh-In-Motion (WIM), } \\
\text { Vehicle Classification }\end{array}$ \\
\hline & Capacitive Sensor & 2008 & Malla et al. [18] & $\begin{array}{l}\text { Light Weight, Small Volume, } \\
\text { Portability }\end{array}$ & Load \\
\hline & Strip Strain Sensor & $\begin{array}{l}2008 \\
a, b\end{array}$ & $\begin{array}{c}\text { Zhang et al. } \\
{[19,20]}\end{array}$ & Simple and Efficient & $\begin{array}{l}\text { WIM and Vehicle } \\
\text { Classification }\end{array}$ \\
\hline & $\begin{array}{l}\text { Piezoelectric } \\
\text { Transduction } \\
\end{array}$ & 2011 & \multirow[b]{2}{*}{$\begin{array}{l}\text { Lajnef et al. } \\
{[21,22]}\end{array}$} & $\begin{array}{c}\text { Self-Powered, Piezo-Floating- } \\
\text { Gate, Array }\end{array}$ & Strain and Temperature \\
\hline & $\begin{array}{l}\text { Smart Pavement } \\
\text { Monitoring System }\end{array}$ & 2013 & & $\begin{array}{c}\text { Self-Powered, Continuous, } \\
\text { Non-Volatile Storage, Small } \\
\text { Size, Wireless } \\
\text { Communication, High } \\
\text { Robustness } \\
\end{array}$ & Strain \\
\hline & $\begin{array}{l}\text { Optical Fiber Bragg } \\
\text { Grating (OFBG) } \\
\text { Sensor } \\
\end{array}$ & 2012 & Zhou et al. [23] & 3D Monitoring & Strain \\
\hline & $\begin{array}{c}\text { Micro- } \\
\text { Electromechanical } \\
\text { System (MEMS) } \\
\text { Sensor } \\
\end{array}$ & 2014 & Yang [24] & $\begin{array}{c}\text { Health Monitoring, Wireless, } \\
\text { High Survivability }\end{array}$ & $\begin{array}{l}\text { Temperature, Moisture, } \\
\text { Strain }\end{array}$ \\
\hline & $\begin{array}{l}\text { Mobile Sensing } \\
\text { Technologies }\end{array}$ & 2015 & Yi et al. [25] & $\begin{array}{c}\text { Smartphone Probe Car (SPC) } \\
\text { System, Crowdsourcing- } \\
\text { Based } \\
\end{array}$ & $\begin{array}{l}\text { Surface Anomalies } \\
\text { (Potholes and Bumps) }\end{array}$ \\
\hline \multirow{2}{*}{$\begin{array}{l}\text { Optical } \\
\text { Image } \\
\text { Processing } \\
\text { (OIP) }\end{array}$} & $\begin{array}{l}\text { Digital Image } \\
\text { Collection and } \\
\text { Analysis, PDA }\end{array}$ & 2006 & Cafiso et al. [26] & $\begin{array}{l}\text { Automated Pavement } \\
\text { Image Collection and } \\
\text { Distress Detection }\end{array}$ & $\begin{array}{c}\text { Distress (Cracks, Potholes } \\
\text { and Patching) }\end{array}$ \\
\hline & $\begin{array}{l}\text { Automatic Image } \\
\text { Processing }\end{array}$ & 2011 & $\begin{array}{l}\text { Chambon \& } \\
\text { Moliard [27] }\end{array}$ & $\begin{array}{c}\text { Noninvasive, Crack } \\
\text { Detection }\end{array}$ & Processed Images \\
\hline \multirow[t]{2}{*}{ In-Situ Test } & $\begin{array}{c}\text { Dynamic Cone } \\
\text { Penetrometer (DCP) }\end{array}$ & 2014 & Ahsan [28] & $\begin{array}{c}\text { Simple Method, Less Time } \\
\text { Consuming in Practical } \\
\text { Applications, Less } \\
\text { Maintenance, Higher } \\
\text { Accuracy } \\
\end{array}$ & DCPI Profile \\
\hline & Geogauge & & & Portable Device & In-Situ Stiffness \\
\hline \multirow{2}{*}{$\begin{array}{l}\text { Geographic } \\
\text { Information } \\
\text { System } \\
\text { (GIS) }\end{array}$} & $\begin{array}{c}\text { GIS Model } \\
\text { Integrated with LCA } \\
\text { and LCO } \\
\end{array}$ & 2012 & Zhang et al. [3] & Sustainable, Economic & $\begin{array}{l}\text { Collect, Manage and } \\
\text { Visualizing Pavement } \\
\text { Information Data } \\
\end{array}$ \\
\hline & $\begin{array}{c}\text { GIS Based } \\
\text { Application, } \\
\text { Geodatabase Input } \\
\end{array}$ & 2017 & $\begin{array}{c}\text { Acquah \& Fosu } \\
{[29]}\end{array}$ & $\begin{array}{l}\text { User-Friendly, Cheap, Multi- } \\
\text { Criteria Decision Analysis }\end{array}$ & $\begin{array}{c}\text { Road Condition Score in } \\
\text { Percentage }\end{array}$ \\
\hline
\end{tabular}

\subsection{METHODOLOGY}

This study was carried out with two main purposes: first, to present the pavement monitoring modes introduced by previous researchers and present a comprehensive review of each mode, and secondly to do a comparative study of three selected modes in term of five indicators, i.e. cost, time, safety, accuracy, and sustainability. The first objective of the study is achieved through a literature review in which five types of pavement monitoring modes were identified. They are manual survey, sensor study, insitu testing, optical image processing (OIP), and geographical information system (GIS).
The second objective of this study is to conduct a comparative study of three methods which were selected based on the literature review. Two manual methods, i.e. walking and riding survey, and one smart sensor study and optical image processing each were selected for the comparative study. The three categories were chosen due to their outstanding performance in their respective category. Figure 1 shows the sequence of the method adopted in this study. 


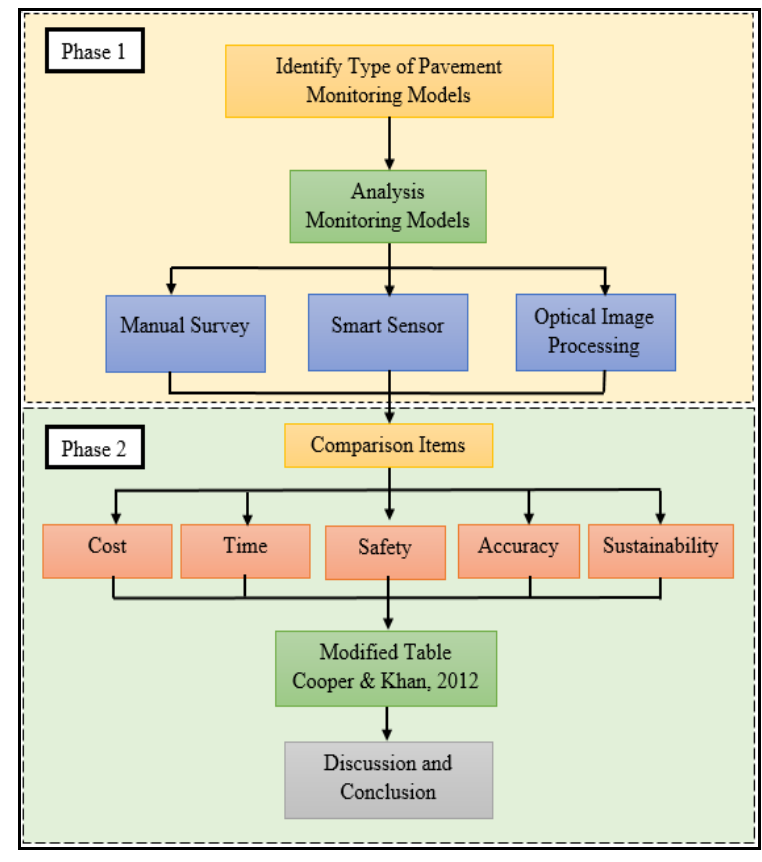

Figure 1 Conceptual Framework of the study
This comparative study used a rating system table to assign average score to each mode. The mode with highest cumulative average score for all five indicators is regarded as the most effective pavement monitoring mode. The components of the rating system are introduced through data quality guidelines [30] as shown in Table 2. The table was modified to suit the aims of this comparative study. The rank for each comparative item is arranged from worst to best. The worst rank is assigned a value of 1 and the best rank is assigned a value of 5. Table 3 presents an overall summary of the three methods. The ranking system shown in Table 4 explains the comparative items in each rank. Each mode will be given score based on the behavior of the mode. In the final stage, the score for each comparative item was summed up to compare the ranking of the modes. Finally, the result and discussion of the comparative study is presented along with a conclusion of the most effective pavement monitoring mode.

Table 2 Data quality guideline

\begin{tabular}{|c|c|c|c|c|c|}
\hline & \multicolumn{5}{|c|}{ Worse to Best Score } \\
\hline & 1 & 2 & 3 & 4 & 5 \\
\hline Time related coverage & $\begin{array}{c}\text { More than } 20 \\
\text { years }\end{array}$ & 20 to 15 years & 15 to 10 years & 10 to 5 years & Less than 5 years \\
\hline Geographic coverage & $\begin{array}{l}\text { Data from } \\
\text { location with } \\
\text { different } \\
\text { conditions and } \\
\text { regions }\end{array}$ & $\begin{array}{c}\text { Data from } \\
\text { location with } \\
\text { different } \\
\text { conditions but } \\
\text { inside regions }\end{array}$ & $\begin{array}{c}\text { Data from location } \\
\text { with same } \\
\text { conditions but } \\
\text { outside regions }\end{array}$ & $\begin{array}{c}\text { Data from } \\
\text { location with } \\
\text { same conditions } \\
\text { and inside regions }\end{array}$ & $\begin{array}{l}\text { Data from } \\
\text { previous activities } \\
\text { in the same } \\
\text { specific site }\end{array}$ \\
\hline $\begin{array}{l}\text { Precision, completeness } \\
\text { and representativeness }\end{array}$ & $\begin{array}{l}\text { incorrect } \\
\text { assumptions, } \\
\text { inaccurate }\end{array}$ & Missing data & $\begin{array}{c}\text { Only consider } \\
\text { energy } \\
\text { consumption or } \\
\text { emission, accurate }\end{array}$ & $\begin{array}{c}\text { all assumptions } \\
\text { correct, } \\
\text { incomplete } \\
\text { emissions data, } \\
\text { accurate }\end{array}$ & $\begin{array}{l}\text { All emissions, all } \\
\text { assumptions } \\
\text { correct, accurate }\end{array}$ \\
\hline $\begin{array}{l}\text { Consistency and } \\
\text { reproducibility of } \\
\text { methods used }\end{array}$ & $\begin{array}{c}\text { Data acquisition } \\
\text { methods } \\
\text { unknown }\end{array}$ & $\begin{array}{l}\text { Data acquisition } \\
\text { difficult to } \\
\text { reproduce }\end{array}$ & $\begin{array}{l}\text { Methods are } \\
\text { incomplete }\end{array}$ & $\begin{array}{l}\text { Complete } \\
\text { methods but } \\
\text { unclear } \\
\text { assumptions to be } \\
\text { reproducible }\end{array}$ & $\begin{array}{l}\text { Data from } \\
\text { accepted test } \\
\text { methods, steps } \\
\text { understood, } \\
\text { reproducible }\end{array}$ \\
\hline
\end{tabular}


Table 3 Summary of Comparison of the Modes

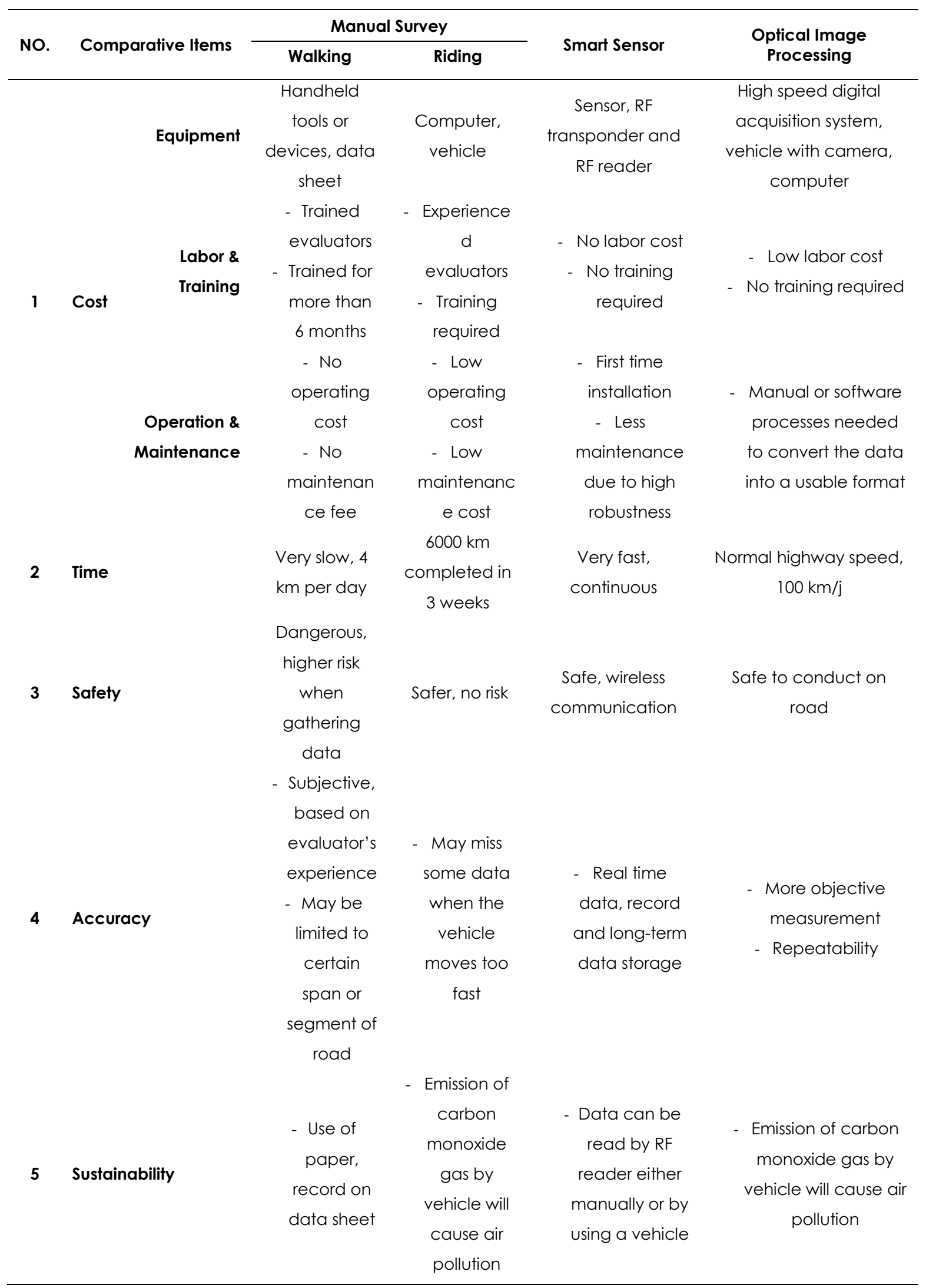


Table 4 Rating System for Comparative Items

\begin{tabular}{|c|c|c|c|c|c|}
\hline \multirow{2}{*}{ Compared Item } & \multicolumn{5}{|c|}{ Rating System } \\
\hline & 1 & 2 & 3 & 4 & 5 \\
\hline $\begin{array}{c}\text { Cost } \\
(\text { For } 1 \mathrm{~km})\end{array}$ & $\begin{array}{c}\text { Very Expensive } \\
\text { RM } 400 \text { and } \\
\text { above }\end{array}$ & $\begin{array}{c}\text { Expensive } \\
\text { RM 301-RM } 400\end{array}$ & $\begin{array}{c}\text { Moderate } \\
\text { RM 201-RM } 300\end{array}$ & $\begin{array}{c}\text { Cheap } \\
\text { RM 101-RM } 200\end{array}$ & $\begin{array}{l}\text { Very Cheap } \\
\text { Below RM } 100\end{array}$ \\
\hline $\begin{array}{c}\text { Time } \\
\text { (For } 1000 \text { km) }\end{array}$ & $\begin{array}{c}\text { Very Slow } \\
\text { More than } 1 \\
\text { month }\end{array}$ & $\begin{array}{c}\text { Slow } \\
2 \text { weeks to } 1 \\
\text { month }\end{array}$ & $\begin{array}{c}\text { Fair } \\
1 \text { to } 2 \text { weeks }\end{array}$ & $\begin{array}{c}\text { Fast } \\
1 \text { to } 6 \text { days }\end{array}$ & $\begin{array}{c}\text { Very Fast } \\
\text { Less than } 1 \text { day }\end{array}$ \\
\hline Safety & $\begin{array}{c}\text { Very dangerous, } \\
\text { may cause } \\
\text { accident. }\end{array}$ & $\begin{array}{c}\text { Dangerous, } \\
\text { exposure to } \\
\text { hazard. }\end{array}$ & Lower risk, safe. & $\begin{array}{l}\text { Safe to conduct } \\
\text { on road. }\end{array}$ & $\begin{array}{l}\text { Very safe, no } \\
\text { direct contact } \\
\text { with traffic. }\end{array}$ \\
\hline Accuracy & $\begin{array}{l}\text { Inaccurate or } \\
\text { wrong data. }\end{array}$ & $\begin{array}{c}\text { Low accuracy, } \\
\text { some missing } \\
\text { data. }\end{array}$ & $\begin{array}{l}\text { Accurate, data } \\
\text { considered } \\
\text { acceptable. }\end{array}$ & $\begin{array}{l}\text { Accurate, most of } \\
\text { the required data } \\
\text { is retrieved. }\end{array}$ & $\begin{array}{c}\text { High accuracy } \\
\text { with real-time } \\
\text { data. }\end{array}$ \\
\hline Sustainability & $\begin{array}{c}\text { Not related to any } \\
\text { sustainability } \\
\text { practices. }\end{array}$ & $\begin{array}{c}\text { Does not } \\
\text { implement } \\
\text { sustainable } \\
\text { practice, cause } \\
\text { certain damage } \\
\text { to environment. }\end{array}$ & $\begin{array}{l}\text { Minimal } \\
\text { implementation of } \\
\text { sustainable } \\
\text { practice, potential } \\
\text { risk to the } \\
\text { environment. }\end{array}$ & $\begin{array}{l}\text { Sustainable } \\
\text { practices, effort to } \\
\text { reduce pollution. }\end{array}$ & $\begin{array}{l}\text { Support overall } \\
\text { sustainable } \\
\text { practice, } \\
\text { environmentally } \\
\text { friendly. }\end{array}$ \\
\hline
\end{tabular}

\subsection{RESULTS AND DISCUSSION}

Following the tabulation of the rating system, the ranking process can be commenced by giving a score to each of the monitoring modes. The comparative items begin with cost, time, safety, accuracy, and end with sustainability.

\subsection{Cost Comparison}

In the present study, a new rating system was introduced for the cost indicator (Table 5) to give a more specific and detail explanation about cost allocation. Since each mode has been assigned with different types of cost, the cost indicator was divided into three categories, i.e. price of equipment, labor and training costs, and operating and maintenance cost.

Table 6 shows the scores for the average costs of all three pavement monitoring methods. The summary presented shows that manual walking survey does not require a high equipment cost. The cost for equipment in a walking survey is for handheld tools and paper; it requires the lowest cost (score 5) when compared with other method. The given a score of the equipment cost for the smart sensor mode, is slightly higher than other modes because of the high cost of sensor equipment. Each sensor consists of several components, such as a piezoelectric transducer, a floating gate, and an RF transponder, which is the highest equipment cost (score one) among all methods. The equipment used in optical image processing includes a high-speed digital acquisition system, which essentially means a vehicle equipped with a camera, and computers might be used to compute pavement distress data.

The second cost indicator is labor and training costs. Expenses for training evaluators to conduct manual survey method cannot be avoided. A welltrained evaluator is crucial in ensuring that the survey is carried out correctly and comprehensively [6]. The labor cost for the walking survey is rather high. Evaluators must undergo over 6 weeks of training before they are qualified to conduct their walking survey under tedious condition [32]. This means that the survey is labor intensive during the data collection period. Thus, walking survey was given the lowest score for their labor and training costs. The 
riding survey was given a score of two due to the fact that compared to walking survey, it is less labor intensive. Smart sensor, however, does not involve any labor and training costs during the data collection process. Thus, it was given the highest score. Optical image processing involves a low labor cost since a driver is needed for the mobile laboratory.

The third cost indicator is operation and maintenance costs. As it is shown in Table 3, manual walking survey does not involve any operation and maintenance costs. The cost of operating and maintenance in riding survey is low, where the cost incurred is vehicle operation cost (VOC). The sensors used are this study requires very little maintenance since they are self-powered and very robust. There is a first-time installation cost to embed the smart sensors under the pavement. It should be noted that, if the sensors broke down or malfunctioned, the operation cost would be higher than those of other modes. For these reasons, the smart sensor was given the highest score in maintenance and operation. The operation cost for optical image processing method is lower compared with smart sensor. The operation cost in this method mainly for operating the vehicle and data processing. The maintenance cost in OIP comprises operation of the vehicle and ensuring that the cameras are always in a good condition. If the mobile laboratory was not maintained in a good general condition, the accuracy of the gathered data might be compromised.

According to average cost score in Table 6, manual walking survey has the highest average cost score of 3.67, which means that it has the lowest cost in comparison with other modes in this study. The smart sensor has the lowest average cost score of 2.33 (highest cost), which means that it is the most expensive method for PMS.

Table 5 Rating System for Cost Indicator

\begin{tabular}{|c|c|c|c|c|c|}
\hline \multirow{2}{*}{ Cost Indicator } & \multicolumn{5}{|c|}{ Rating System } \\
\hline & 1 & 2 & 3 & 4 & 5 \\
\hline Equipment & Very expensive & Expensive & Affordable & Cheap & Very cheap \\
\hline Labor + Training & $\begin{array}{l}\text { High labor and } \\
\text { training costs }\end{array}$ & $\begin{array}{l}\text { Medium labor and } \\
\text { training costs }\end{array}$ & $\begin{array}{l}\text { Low labor and } \\
\text { training costs }\end{array}$ & $\begin{array}{l}\text { Low labor cost } \\
\text { and no training } \\
\text { cost }\end{array}$ & $\begin{array}{l}\text { No labor and } \\
\text { training costs }\end{array}$ \\
\hline $\begin{array}{l}\text { Operating + } \\
\text { Maintenance }\end{array}$ & $\begin{array}{l}\text { High conducting / } \\
\text { operating and } \\
\text { maintenance costs }\end{array}$ & $\begin{array}{c}\text { Medium } \\
\text { conducting / } \\
\text { operating and } \\
\text { maintenance costs }\end{array}$ & $\begin{array}{l}\text { Low conducting / } \\
\text { operating and } \\
\text { maintenance costs }\end{array}$ & $\begin{array}{l}\text { Low conducting / } \\
\text { operating cost and } \\
\text { no maintenance } \\
\text { cost }\end{array}$ & $\begin{array}{l}\text { No conducting / } \\
\text { operating and } \\
\text { maintenance costs }\end{array}$ \\
\hline
\end{tabular}

Table 6 Average Cost Score ranking system

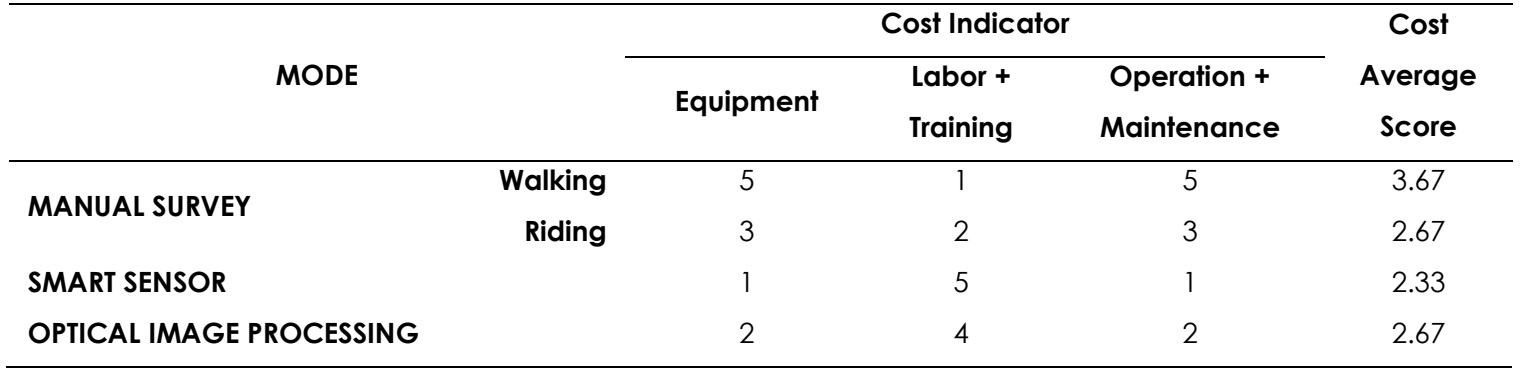

\subsection{Time Taking}

Table 4 indicated the scores for the time indicator, where the ranking is from the slowest (score one) to the fastest (score five). The mode which completes the monitoring $1000 \mathrm{~km}$ segment of pavement condition in the shortest period of time is ranked as the best.
Manual survey apparently took the longest time to be completed, as have been shown in previous studies, such as the study conducted by the Arizona Department of Transportation (ADOT) [6]. Onn [32] stated that manual walking survey is very time consuming and tedious and is only able to gather data for a $4-\mathrm{km}$ segment per day. This method was given a score of one. The riding survey was able to 
cover a longer segment, in less time [6]. This survey was conducted using a very slow-moving vehicle [33]. The speed of the vehicle used in this survey is around $30-40 \mathrm{~km} / \mathrm{h}$ since the evaluator must inspect, identify, and record pavement distresses while sitting in a moving vehicle. Onn [32] has shown that a manual riding survey which covered $1000 \mathrm{~km}$ was completed in three weeks. This riding survey was given score two. The smart sensor method is capable of continuously monitoring pavement strain events [22]. This mode is given the highest score by virtue of its ability to provide real time data very quickly. The smart sensors embedded below the pavement are able to store strain data less than a day old and retrieve the data very quickly. The ability of the optical image processing method to gather pavement data is dependent on the speed of the mobile laboratory. The OIP method is essentially carried out at a typical highway speed [34]. The network-level data collection method is technique which makes it possible to gather data for a large network in a relatively short period of time through the use of modern (and still evolving) technologies which automated much of the data acquisition and processing [34]. Thus, OIP mode is given a score of four for its time allocation.

\subsection{Safety Assurance}

Timm et al. [6], Wolters et al. [15], Xue et al. [8], and Attoh-Okine and Adarkwa [16] contended that manual survey exposes evaluators to hazards during data collection. For this reason, ADOT only conducts surveys when the weather permits [6]. Many states are currently transitioning or have made the transition from manual pavement condition surveys to automated pavement condition surveys due to safety and efficiency issues which are present in manual condition surveys [6]. The safety indicators for the walking survey mode are presented in Table 3. Table 4 shows the ranking used for the danger and hazard exposure. The walking survey was given a score of two while the riding survey was given a score of three due to the lower risk. The evaluators conducting riding survey are not exposed to the dangers of being on the road side. Instead the survey was done with the evaluators being driven in a vehicle. The smart sensor mode does not expose evaluators to any kind of hazard. This method does not require any human involvement subsequent to its installation. Hence the smart sensor mode is given a score of 4 which means that in can be safely conducted on the road. The data retrieval method in OIP is similar to manual riding survey where the data is retrieved while riding on a moving vehicle. The main difference between the two methods is that in the riding survey data collection is done by humans (manually) while in OIP it is done using a digital camera (automated). Attoh-Okine and Adarkwa [16] reported that among the benefits of automated distress survey (such as OIP) is safety for survey crews and faster and more objective data. Optical image processing was given a score of four in terms of safety. This method is given a better score than riding survey since the evaluator in the vehicle does not have to deal the problem of missing data because all the data will automatically be recorded by the cameras. Therefore, the OIP mode offers a much safer method for collecting data.

\subsection{Data Accuracy}

The fourth item compared in this study is accuracy of data. The availability of a more accurate data would allow agencies to make better decision with regard to their PMS strategy. Attoh-Okine and Adarkwa [16] indicated that the data collected through manual walking survey tend to more subjective and less accurate since it is influenced by evaluators' experience. According to Bogus et al. [18], it is not uncommon for manual distress surveys to result in disparity of data. The disparity in distress data is a critical issue in the attempt to improve the effectiveness of pavement condition index as a reliable indicator and useful tool for pavement management systems (PMSs). Even though evaluators must undergo training prior to working in the field, the dataset produced by experienced and inexperienced evaluators will invariably be different. Prakash et al. [35] compared the disparity in the data gathered by experienced (at least 5 years of experience) and inexperienced evaluators. The research concluded that, to improve the quality of manual distress data, evaluators must undergo regular training, and they should be tested to identify and minimize evaluator's bias with regard to specific distresses. It should be noted that manual walking survey is sometimes limited to a certain segment of the road [34]. Humans have limited ability and it is not possible for any evaluator to survey the entire route if the distance is too long. Hence walking survey is given a score of three, which means that the data is considered acceptable. Riding survey could produce even less accurate data when compared with walking survey. The evaluator might not notice pavement distress due to the high speed of the vehicle if data collection is not automated. All observations, inspection, identification and recording should be done by a trained individual. Transcription error could occur, especially when evaluators try to record the information in a record book within a very short span of time. This error was presented on the discussion from a study by Attoh-Okine and Adarkwa [16]. Hence, riding survey is given a score of two, which indicates low accuracy since data could be erroneously recorded or missed during the data collection process. The design of sensors used in the smart sensor mode makes it possible for compute and store data in a long period as well as recording data automatically in real time. Lajnef et al. [22] have shown that these sensors are very robust and functions continuously. This mode has very high accuracy and hence is given the highest score. The accuracy of the OIP mode is higher than manual 
survey and gives an objective evaluation of the pavements. This mode can be repeated if there is a need to do multiple runs over the entire road width. According to Attoh-Okine and Adarkwa [16] this system utilizes five mounted video cameras, i.e. two in front, two in the rear, and one each on top and in the center. Each camera covers a span of about 30 square feet (2.8 square meters) with a $50 \%$ overlap at $55 \mathrm{mph}$ (below $90 \mathrm{~km} / \mathrm{h}$ ). The research also found that the automated OIP mode could cover the footprint of data collection vehicle. Therefore, the accuracy from this mode is not as good as that of the smart sensor. This mode is given a score of four which indicates that this mode is accurate and is able to gather most of the required data.

\subsection{Sustainability and Environmental Impacts}

Regarding sustainable development, pavement asset management systems should be able to account for sustainability indicators, such as user time delay caused by preservation activities, additional fuel consumption caused by deterioration of pavement surface, and other environmental impacts $[3,36]$. Two factors in manual walking survey could have positive/negative influence on sustainability. Since this is the only mode which requires walking in the data collection stage, it could consider as an environmentally-friendly mode. It does not cause air pollution or impact assessment of carbon emission into the environment. On the other hand, usage of paper data sheets (to record the pavement distress data) makes this method less sustainable rather than digital data storage. The use of paper can be replaced with other handheld tools or devices which would allow data to be gathered digitally. The manual walking survey is given a score of three based for its sustainable approach. In the riding survey, the risk to environment is via the release of carbon monoxide produced by the vehicle. This problem can be avoided by using eco-friendly vehicles which would reduce gas emission that contribute to air pollution. Unlike walking survey, most riding surveys use digital data collection technique since the vehicles can be fitted with electronic devices, such as computer, to conduct the survey. Evaluators would be able to record the data digitally and can even easily and directly input the data into appropriate software. For these reasons, riding survey was given a score of four with regard to sustainability. The smart sensor mode can be considered as an eco-friendly mode. The use of automatic and self- powered sensor has eliminated the need to use vehicles during the data collection process. This also means that there is no gas emission. Vehicles are only used periodically to retrieve data via wireless communication from the RF reader. Data retrieval can also be done manually if the distance for data retrieval is not too far. The smart sensor mode was given a score of five for sustainability. In this study, the OIP mode was given a score of three since a customized van was used to conduct the survey due to the difficulty in obtaining an eco-friendly car. Cameras and electronic devices were mounted to the mobile laboratory. Thus, the problem of carbon monoxide emission cannot be avoided.

Once the scoring process for each of the modes in five comparison items has been completed, the average scores were computed, and the results are shown in Table 7. The mode with the highest average score is considered as the most effective pavement monitoring mode. The smart sensor mode has the highest average score of 4.27. The optical image processing mode has the next highest score of 3.53 . The scores for walking and riding methods are almost similar, with the riding survey showing a slightly better score than walking survey. Both manual surveys (walking and riding) are ranked the lowest, with the walking survey having a score of 2.73 and riding survey a score of 2.53 .

\subsection{CONCLUSION}

The present study reviewed five major pavementmonitoring modes (Manual Survey, Sensors Studies, Optical Image Processing, In-situ Test and Geographic Information System) which have been conducted in previous studies. Three modes were chosen for a comparative study, i.e. manual survey (comprising walking and riding surveys), smart sensor, and optical image processing. Comparison was done base on five indicators, i.e. cost, time, safety, accuracy and sustainability, to determine which mode is the most effective in performing pavement monitoring functions. Results show that the smart sensor method is the best overall mode for pavement monitoring. As a conclusion, it is hoped that the findings of this study would help relevant agencies make a decision with regard to the most effective pavement monitoring mode for their PMS strategy relative to the constraining factors they may have. 
Table 7 Average Score of the Five Indicators

\begin{tabular}{|c|c|c|c|c|c|c|c|}
\hline \multirow{2}{*}{ MODE } & & \multicolumn{5}{|c|}{ Rating Comparison Item } & \multirow{2}{*}{ Average Score } \\
\hline & & Cost & Time & Safety & Accuracy & Sustainability & \\
\hline \multirow{2}{*}{ MANUAL SURVEY } & Walking & 3.67 & 1 & 2 & 3 & 3 & 2.53 \\
\hline & Riding & 2.67 & 2 & 3 & 2 & 4 & 2.73 \\
\hline \multicolumn{2}{|l|}{ SMART SENSOR } & 2.33 & 5 & 4 & 5 & 5 & 4.27 \\
\hline \multicolumn{2}{|c|}{ OPTICAL IMAGE PROCESSING } & 2.67 & 4 & 4 & 4 & 3 & 3.53 \\
\hline
\end{tabular}

\section{Acknowledgement}

The authors express their gratitude to the University Kebangsaan Malaysia (DIP-2017-004) for the financial support of this work.

\section{References}

[1] APWA (American Public Works Association). 1993. Best Management Practices for Storm Water Permit Compliance. American Public Works Association, Chicago, IL.

[2] Khan, M. A., Ahmed, A., \& Kayani, W. I. U. H. 2018. Optimal Timing for Lane (s) Addition to an Existing Highway: A Benefit-cost Approach. Arabian Journal for Science and Engineering. 1-14.

[3] Zhang, H., Keoleian, G. A., \& Lepech, M. D. 2012. Networklevel Pavement Asset Management System Integrated with Life-cycle Analysis and Life-cycle Optimization. Journal of infrastructure Systems. 19(1): 99-107.

[4] Salpisoth, H. 2014. Simple Evaluation Methods for Road Pavement Management In Developing Country.

[5] Chan, C. Y., Huang, B., Yan, X., \& Richards, S. 2010. Investigating Effects of Asphalt Pavement Conditions on Traffic Accidents in Tennessee Based on the Pavement Management System (PMS). Journal of Advanced Transportation. 44(3): 150-161

[6] Timm, D. H., \& McQueen, J. M. 2004. A Study of Manual vs. Automated Pavement Condition Surveys. Alabama, EE. UU: Auburn University.

[7] Santos, J., \& Ferreira, A. 2013. Life-cycle Cost Analysis System for Pavement Management at Project Level. International Journal of Pavement Engineering. 14(1): 7184.

[8] Xue, W., Wang, D. \& Wang, L. 2012. A Review and Perspective about Pavement Monitoring. International Journal of Pavement Research and Technology. 5(5): 295302.

[9] Babashamsi, P., Golzadfar, A., Yusoff, N. I. M., Ceylan, H., \& Nor, N. G. M. 2016a. Integrated Fuzzy Analytic Hierarchy Process and VIKOR Method in the Prioritization of Pavement Maintenance Activities. International Journal of Pavement Research and Technology. 9(2): 112-120.

[10] Torres-Machi, C., Chamorro, A., Videla, C., Pellicer, E. \& Yepes, V. 2014. An Iterative Approach for the Optimization of Pavement Maintenance Management at the Network Level - Proquest. Hindawi Publishing Corporation the Scientific World Journal Article. 201: 11.

[11] Nikolaou, A. 2016. Study of Asphalt Pavement Deterioration through Remote Sensing. MSC (Master of Science) Thesis. Cyprus University of Technology. 41 pages.

[12] Raya, J. K. 1992. A Guide to Visual Assessment of Flexible Pavement Surface Conditions. Kuala Lumpur. IKRAM.

[13] Salleh, I. M., Toole, T., Bennett, D., \& Hasan, Z. 2006. Evaluation and Monitoring of Toll Road Pavements in
Malaysia from an Owner's Perspective. In Research into Practice. 22nd ARRB Conference ARRB Group Limited.

[14] Asphalt Institute. 2017. Asphalt Pavement Distress

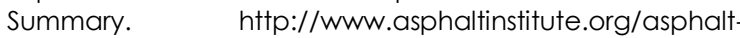
pavement-distress-summary/ [24 November 2017].

[15] Wolters, A., Zimmerman, K., Schattler, K., \& Rietgraf, A. 2011. Implementing Pavement Management Systems for Local Agencies: Implementation Guide (No. ICT-1 1-094-1).

[16] Attoh-Okine, N., \& Adarkwa, O. 2013. Pavement Condition Surveys-Overview of Current Practices. Delaware Center for Transportation, University of Delaware: Newark, DE, USA.

[17] Cosentino, P. J., \& Grossman, B. G. 2000. Optimization and Implementation of Fiber Optic Sensors for Traffic Classification and Weigh-in-Motion Systems (Phase 3) (No. FL/DOT/RMC/06650-7754).

[18] Malla, R. B., Sen, A., \& Garrick, N. W. 2008. A Special Fiber Optic Sensor for Measuring Wheel Loads of Vehicles on Highways. Sensors. 8(4): 2551-2568.

[19] Zhang, W., Suo, C., \& Wang, Q. 2008. A Novel Sensor System for Measuring Wheel Loads of Vehicles on Highways. Sensors. 8(12): 7671-7689.

[20] Zhang, W., Wang, Q., \& Suo, C. 2008. A Novel Vehicle Classification Using Embedded Strain Gauge Sensors. Sensors. 8(11): 6952-6971.

[21] Lajnef, N., Rhimi, M., Chatti, K., Mhamdi, L., \& Faridazar, F. 2011. Toward an Integrated Smart Sensing System and Data Interpretation Techniques for Pavement Fatigue Monitoring. Computer-aided Civil and Infrastructure Engineering. 26(7): 513-523.

[22] Lajnef, N., Chatti, K., Chakrabartty, S., Rhimi, M, Sarkar, P. 2013. Smart Pavement Monitoring System. Michigan State University. 146 pages.

[23] Zhou, Z., Liu, W., Huang, Y., Wang, H., Jianping, H., Huang, M., \& Jinping, O. 2012. Optical Fiber Bragg Grating Sensor Assembly for 3D Strain Monitoring and Its Case Study in Highway Pavement. Mechanical Systems and Signal Processing. 28: 36-49.

[24] Yang, S. 2014. Health Monitoring of Pavement Systems Using Smart Sensing Technologies. Doctoral Dissertation. lowa State University.

[25] Yi, C. W., Chuang, Y. T., \& Nian, C. S. 2015. Toward Crowdsourcing-based Road Pavement Monitoring by Mobile Sensing Technologies. IEEE Transactions on Intelligent Transportation Systems. 16(4): 1905-1917.

[26] Casifo, S., La Cava, G., Montella, A., Pappalardo, G. 2006. A Procedure to Improve Safety Inspections Effectiveness and Reliability on Rural Two-lane Highways. The Baltic Journal of Road and Bridge Engineering. 1(3): 143-150.

[27] Chambon, S. \& Moliard, J. M. 2011. Automatic Road Pavement Assessment with Image Processing: Review and Comparison. International Journal of Geophysics. 2011.

[28] Ahsan, A. N. 2014. Pavement Performance Monitoring using Dynamic Cone Penetrometer and Geogauge during Construction. The University of Texas at Arlington.

[29] Acquah, P. C., \& Fosu, C. 2017. Implementation of Geographic Information System Application in the Maintenance Management of Roads in Ghana: A Case 
Study of Roads in Kumasi Metropolis. American Journal of Geographic Information System. 6(3): 90-102.

[30] Cooper, J. S., \& Kahn, E. 2012. Commentary on Issues in Data Quality Analysis in Life Cycle Assessment. The International Journal of Life Cycle Assessment. 17(4): 499503.

[31] Babashamsi, P. 2017. PAVECO: An Integrated Life Cycle Cost Analysis and Life Cycle Assessment toward Sustainable Airport Pavement Management System. Thesis PhD. Universiti Kebangsaan Malaysia.

[32] Onn, L. 2001. Pavement Data Collection Strategy for JKR Malaysia. In ARRB Transport Research LTD Conference, 20th, 2001, Melbourne, Victoria, Australia.

[33] Bogus, S. M., Song, J., Waggerman, R. \& Lenke, L. R. 2010 Rank Correlation Method for Evaluating Manual
Pavement Distress Data Variability. Journal of Infrastructure Systems. 16(1): 66-72.

[34] Pierce, L. M., McGovern, G. \& Zimmerman, K. A. 2013. Practical Guide for Quality Management of Pavement Condition Data Collection. 170.

[35] Prakash, A., Sharma, B. N., \& Kazmierowski, T. J. 1994, May. Investigation into Observational Variations in Pavement Condition Survey. Proceedings of the 3rd International Conference on Managing Pavements. 2: 290-301.

[36] Babashamsi, P., Md Yusoff, N. I., Ceylan, H., Md Nor, N. G., \& Salarzadeh Jenatabadi, H. 2016b. Sustainable Development Factors in Pavement Life-cycle: Highway/Airport Review. Sustainability. 8(3): 248. 